\title{
Urban farming in the informal settlements of Atteridgeville, Pretoria, South Africa
}

\author{
W van Averbeke* \\ Centre for Organic and Smallholder Agriculture, Department of Crop Sciences, Tshwane University of Technology, \\ Private Bag X680, Pretoria 0001, South Africa
}

\begin{abstract}
The objectives of the study were to provide quantitative information on the material benefits generated from urban farming in order to assess the contribution of this activity to the food security and nutrition of participating households and to explore the meaning of urban agriculture in the livelihood of participants. The study was conducted in five informal settlements of Atteridgeville, Pretoria and involved a pilot study, a household survey and multiple case studies using participants in the different types of urban farming projects as units of data collection and analysis. More than half of the households in the study area participated in urban farming which consisted of home gardening, group gardening and dryland farming in open urban spaces. Active participation was predominantly by women. The contribution to total household income and food security of the different types of farming found in the study area was generally modest but the livelihood benefits derived from urban farming extended far beyond material gain, reducing social alienation and the disintegration of families associated with urban poverty. Lack of space and limited access to water for irrigation were the main constraints that affected participants in urban farming.
\end{abstract}

Keywords: urban agriculture, home gardening, group gardening, dryland farming, irrigation, crop selection, poverty, gender, food security, livelihood, multi-functionality.

\section{Introduction}

Post-apartheid South Africa has levels of poverty not found in most other upper middle income countries (Adato et al., 2004). At the start of the $21^{\text {st }}$ century, an estimated $48 \%$ of the South African population (21.9 million people) lived below the national poverty line (UNDP, 2004). The distribution of income in South Africa was also highly unequal and disparities between rich and poor were worsening as indicated by the increase in the Gini coefficient of the country from 0.60 in 1995 to 0.73 in 2001 (UNDP, 2004). Historically, poverty in South Africa has been associated with race, gender and rurality. In $1999,61 \%$ of black South Africans were poor compared to a mere $1 \%$ of whites (May, 2000), whilst female-headed households were more likely to be poor than male-headed households (Aliber, 2003) and poverty was mostly located in the rural areas. For example, in 1995, $74 \%$ of the poor in South Africa lived in rural areas, where the poverty rate was estimated to be $71 \%$ (Adelzadeh et al., 2001).

During the recent past, particularly between 1991 and 2001, South Africa has experienced accelerated rural to urban migration of black people who previously had been confined to living in designated rural homelands by legislation that restricted their movements and place of residence (Boraine, 2004). Migration is one of the strategies used by the rural poor to improve their livelihood (Swift and Hamilton, 2001; Ellis and Freeman, 2005). However, lack of jobs in the urban areas of South Africa has limited the opportunities of the new arrivals to find employment in the cities. This has resulted in the transfer of poverty from rural to urban areas (May and Rogerson, 1995; Rakodi, 1999;

\footnotetext{
* To whom all correspondence should be addressed.

Jerve, 2001). In the urban areas of South Africa, poverty is particularly concentrated in low-income and informal settlements, which are nearly exclusively occupied by black people (Martin et al., 2000). It is in these settlements that problems of food insecurity and under-nutrition are most likely to occur. For example, Theron (2000) identified a $17 \%$ stunting rate among children aged 12 to 24 months in Concern and Phomolong, two of the five informal settlements of Atteridgeville, Pretoria, where the current study was conducted. She identified inadequate intake of calcium and iron among both stunted and non-stunted children as the most important dietary deficiencies in the study area. Provided that land and other necessary resources are available, production of vegetables for home consumption is one of the most obvious ways in which poor urban households can address these particular deficiencies in their diet (Burgess et al., 1998).

Worldwide, urban agriculture is one of the strategies poor urban residents adopt to reduce poverty and improve their food security (Rogerson, 1993). Several studies have pointed out that this is also the case in South Africa. According to Rogerson (1996), the majority of urban farmers in South Africa produce food as part of their survival strategy and their farming activities are not expansionist enterprises. This was confirmed by Martin et al. (2000) who reported that urban agriculture in Pretoria and Cape Town tended to be associated with lack of formal sector employment and aimed primarily at the production of food for home consumption, which enabled households to save on food expenditure. However, they also pointed out that besides providing food, urban farming performed other important functions, including, social, cultural, developmental, aesthetic and environmental.

Information on urban agriculture in South Africa is largely qualitative. Quantitative information on the material benefits being derived is important when seeking to assess the contribution of urban agriculture to the food security and nutrition of 
participating households. Filling this knowledge gap was one of the objectives of this study. The other objective was to explore the meaning of urban agriculture in the livelihood of participants. These two objectives were pursued by means of a case study.

\section{Materials and methods}

The study was conducted during the period August to October 2001 in the informal settlements of Jeffsville-Op-Die-Berg, Phomolong, Concern, Vergenoeg and Brazzaville which are found on the north-facing slopes of the hills that mark the southern edge of the formal township of Atteridgeville situated in Gauteng Province (Fig. 1) about $10 \mathrm{~km}$ west of the centre of Pretoria (Fig. 2). All five informal settlements were established in 1990 on state land as transitional residential areas to provide people with sites on which they could build temporary accommodation until permanent housing became available in formal low-cost housing projects. Combined, the five settlements counted 11400 households at the time of the survey.

The study consisted of three phases. During the first phase, the different types of urban agricultural projects in the study area were identified by means of transect walks through the five settlements plus unstructured interviews with key informants. The information that was obtained was used to construct the survey instrument used in the second phase of the study.

During the second phase, a sample of 120 households in the study area (obtained using a probability multi-stage sampling procedure) was surveyed using a structured interview schedule and face-to-face interviews. The survey instrument was designed to collect data on the income, expenditure and agricultural activities of households. Household was defined as consisting of all persons who usually lived together and who shared the same bundle of incomes. Detailed information on the sampling procedure and the collection of data are provided by Maswikaneng et al. (2002). A poverty line (Carter and May, 1999) constructed using the Household Subsistence Level for Pretoria determined by Potgieter (1999) and adjusted to September 2001 using the CPI index (Statistics SA, 2007) was used to assess the poverty status of households. Total household income in cash and kind was determined on a monthly basis and converted to adult equivalent income (AEI) to account for household composition when assessing the poverty status. Household expenditure was also determined on a monthly basis and converted to adult equivalent expenditure (AEE). Information on the quantities and monetary values of farm produce were obtained by asking respondents to estimate the amounts of produce they had harvested during the period 01 July 2000 to 30 June 2001 from the different crops they had grown. Respondents were encouraged to express these estimates using the units they were familiar with. A portable scale was used to estimate the mass of the different units that were used for the different crops. The monetary value of the different types of produce was based on the local prices that prevailed at the time of the survey (Maswikaneng, 2003). For each type of produce, the proportions allocated by the responding households to home consumption, donations and sales were determined quantitatively.

The third phase consisted of case studies using participants in the different types of urban agricultural projects found in the study area. The objective of this phase of the study was to obtain holistic information on the meaning of urban agriculture in the livelihoods of participants. Purposive sampling (Strydom, 2005) was used to select representative participants. Each case study involved multiple cycles of data collection, analysis and inter-

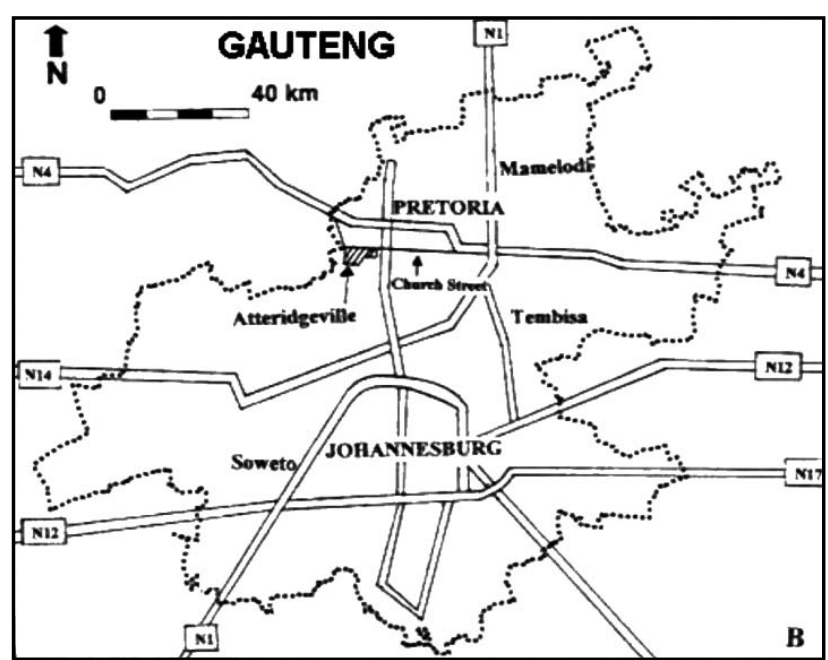

Figure 1

Locality of Atteridgeville study area in Gauteng Province, South Africa

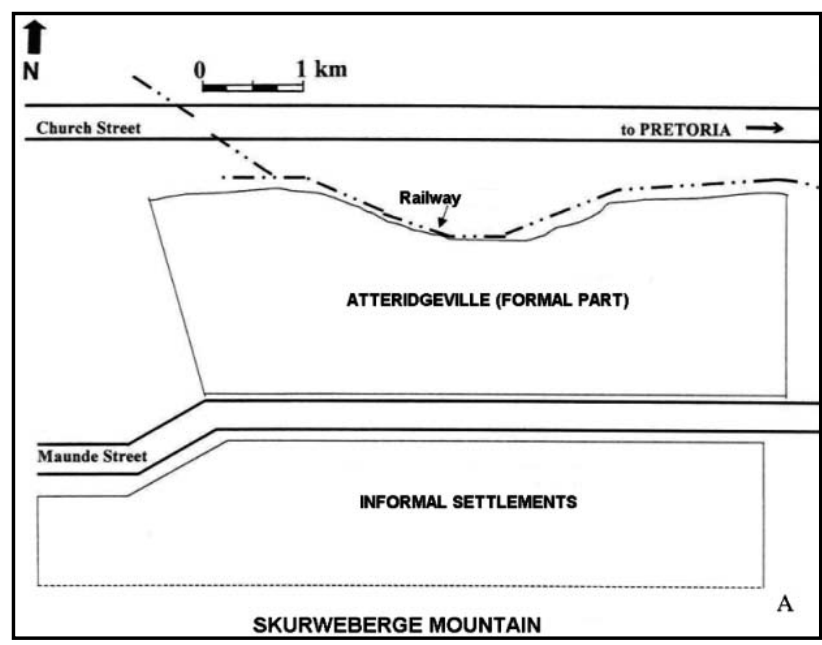

Figure 2

Locality of Atteridgeville township and informal settlement areas in Pretoria (City of Tshwane)

pretation. The data consisted of transcription of the interviews and analysis of the data was by means of multi-level coding (Babbie and Mouton, 2001; De Vos, 2005).

\section{Results and discussion}

\section{Socio-economic profile of households}

The transitional nature of the five informal settlements of Atteridgeville was reflected in the materials people used to build their dwellings, which consisted mostly of wood and corrugated iron but plastic sheets and cardboards were also used. All households made use of pit latrines. Municipal water was available free-of-charge from a limited number of stand-pipes located in the bottom part of the settlements. As a result, distance to the nearest stand-pipe increased for residential sites that were located higher up the slopes. The residential sites ranged in size between 100 and $400 \mathrm{~m}^{2}$ and regulations prohibited occupation of the individual sites by more than one household. Dwellings occupied only part of the sites leaving space for the establishment of small home gardens. 
Households residing in the five settlements were mostly $(88 \%)$ recent arrivals from rural areas in the Provinces of Limpopo and Mpumalanga. Three-quarters of the households had between three and five members and these were mostly younger than 40 years old. Members aged 65 years and older were rare. The average household counted 4.4 members, which consisted of 1.4 children younger than 15 years old and 3 adults aged 15 years or older. The unemployment rate (people actively looking for work) was $15 \%$. In order of importance, the contribution to mean total household income of employment was $67.1 \%$, public welfare grants $16.0 \%$, service provision $7.2 \%$, trade $7.0 \%$, transfers by kin $2.5 \%$ and agriculture $0.2 \%$. The overall mean monthly income of households in the area was R1 522 .

Fifty-four percent of the households that were surveyed were actively involved in some form of agriculture, but the mean monthly income these households derived from agriculture in cash or kind only amounted to R5.84, which represented $0.4 \%$ of their total monthly household income. Statistically, the difference between the mean monthly income of farming households (R1 572) and nonfarming households (R1 462) was not significant $(p \leq 0.05)$, but the two categories of households did differ significantly $(p \leq 0.05)$ in terms of the unemployment rate of the 'woman of the house' (female head or spouse of male head) and the income of the male head. The rate of unemployment of the 'woman of the house' was higher among farming households $(61 \%)$ than among non-farming households (49\%) and the monthly income of the male head of household was higher among farming households (R1 475) than among non-farming households (R1 025).

Thirty-three percent of the households in the area had monthly adult equivalent incomes (AEI) higher than the poverty line of R553 and were categorised as non-poor. Eight percent had a monthly AEI that was less than half the poverty line (R277) and were categorised as ultra-poor. The monthly AEI of the remaining 59\% of households, which were categorised as poor, ranged between R277 and R553. Poverty was associated with household size. On average, the non-poor households had 3.4 members, the poor 4.8 and the ultra-poor 6.6. Proportionally, farming was most common among the ultra-poor $(63 \%)$ and least common among the non-poor (45\%), but statistically the differences in the relative frequencies of farming among the three poverty categories were not significant $(p \leq 0.05)$. The expenditure patterns of households categorised by poverty status presented in Table 1 show that, in absolute terms, expenditure on food increased as poverty was reduced. Proportionally expenditure on food declined from a mean of $66 \%$ of total expenditure among the ultra-poor households to $48 \%$ among the poor and $31 \%$ among the non-poor. The inverse relationship between proportional expenditure on food and AEI applied to both farming and non-farming households (Fig. 3).

\section{Agricultural production}

Urban agriculture in the study area was limited to the production of crops, which occurred in home gardens, open urban spaces and group gardens. Selected characteristics of these three types of urban farming are presented in Table 2. Urban farming in the study area was clearly a female domain and was practised mainly by middle-aged and elderly women.

Home gardening was by far the most common type of urban farming in terms of participation rate. It occurred on small parcels of land around the dwellings. The small scale of the home gardens partially explained the modest annual production, which consisted mainly of western vegetables. Pumpkins and sweetpotatoes were the only traditional crops that featured. Home gardens were irrigated using hosepipes that were connected to the stand pipes or by carrying water in buckets filled from stand pipes. In one instance, grey water was used for irrigation. The prevailing practice was supplementary rather than full irrigation. The key constraints in home gardening were limited access to land followed by limited access to water. Schmidt and Vorster

\begin{tabular}{|c|c|c|c|c|c|c|}
\hline \multicolumn{7}{|c|}{$\begin{array}{c}\text { TABLE } 1 \\
\text { Average expenditure of households in the informal settlements } \\
\text { of Atteridgeville by poverty category and engagement in urban } \\
\text { farming }(2001 ; n=120)\end{array}$} \\
\hline \multirow[t]{2}{*}{ Expenditure } & \multicolumn{3}{|c|}{ Farming households $(n=65)$} & \multicolumn{3}{|c|}{$\begin{array}{c}\text { Non-farming households } \\
(\mathrm{n}=55)\end{array}$} \\
\hline & $\begin{array}{l}\text { Non- } \\
(n=\end{array}$ & $\begin{array}{c}\text { Poor } \\
(n=41)\end{array}$ & $\begin{array}{l}\text { Ultra- } \\
\text { poor } \\
(n=6)\end{array}$ & $\begin{array}{c}\text { Non- } \\
\text { poor } \\
(n=22)\end{array}$ & $\begin{array}{c}\text { Poor } \\
(n=30)\end{array}$ & $\begin{array}{l}\text { Ultra- } \\
\text { poor } \\
(n=3)\end{array}$ \\
\hline & \multicolumn{6}{|c|}{$\left(\mathrm{R}\right.$ adult equivalent ${ }^{-1}$ month $\left.^{-1}\right)$} \\
\hline Food & 229.00 & 187.65 & 154.58 & 233.84 & 203.28 & 147.71 \\
\hline Cleaning & 20.32 & 17.48 & 12.52 & 23.24 & 44.37 & 13.02 \\
\hline Energy & 44.33 & 33.49 & 19.13 & 4 & 37.01 & 23.00 \\
\hline Medical & & 6.80 & 3.19 & 15.70 & 3.02 & 2.75 \\
\hline Education & 18.89 & 12 & 6.56 & 29.34 & 9.14 & 5.23 \\
\hline Transport & 68.69 & 31.25 & 14.10 & 72.39 & 37.39 & 11.97 \\
\hline Remittances & 156.86 & 12.94 & 0.00 & 60.07 & 22.76 & 0.00 \\
\hline Agriculture & 1.59 & 0.64 & 2.95 & 0.00 & 0.00 & 0.00 \\
\hline Durables & 180.31 & 49.38 & 14.89 & 127.42 & 42.21 & 16.06 \\
\hline Leisure & 25.21 & 6.41 & 4.81 & 9.67 & 18.18 & 0.00 \\
\hline Savings & 79.49 & 22.33 & 4.94 & 44.19 & 24.75 & 1.08 \\
\hline TOTAL & 833.14 & 377.49 & 237.67 & 662.09 & 442.11 & 220.82 \\
\hline
\end{tabular}

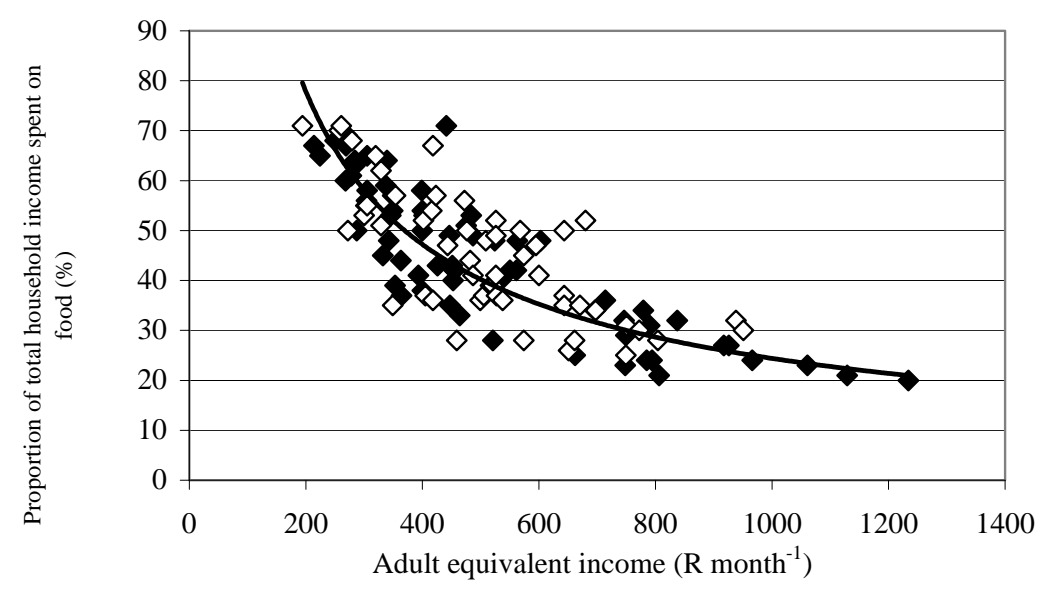

Farming households $\diamond$ Non farming households

Figure 3

Relationship between adult equivalent income per month and the proportion of total income spent on food among households in the informal urban settlements of Atteridgeville (2001, $n=120)$ 


\begin{tabular}{|c|c|c|c|}
\hline \multicolumn{4}{|c|}{$\begin{array}{l}\text { TABLE } 2 \\
\begin{array}{l}\text { Selected characteristics of the three types of urban farming found in the informal } \\
\text { settlements of Atteridgeville }(2001 ; n=65)\end{array}\end{array}$} \\
\hline Characteristic & $\begin{array}{l}\text { Home garden- } \\
\text { ing } \\
(n=54)\end{array}$ & $\begin{array}{l}\text { Group-garden- } \\
\text { ing } \\
(n=3)\end{array}$ & $\begin{array}{l}\text { Crop produc- } \\
\text { tion on open } \\
\text { urban spaces } \\
(n=8)\end{array}$ \\
\hline Gender of participants & $89 \%$ female & $100 \%$ female & $60 \%$ female \\
\hline Average age of participants (years) & 42 & 57 & 53 \\
\hline $\begin{array}{l}\text { Average size of individual unit }\left(\mathrm{m}^{2} \text { partici- }\right. \\
\left.\text { pant }^{-1}\right)\end{array}$ & 26 & 196 & 351 \\
\hline Water supply & Irrigated & Irrigated & Rainfed \\
\hline Choice of crops in order of importance & $\begin{array}{l}\text { Swiss chard, } \\
\text { maize, onions, } \\
\text { other vegetables }\end{array}$ & $\begin{array}{l}\text { Swiss chard, } \\
\text { beetroot, toma- } \\
\text { toes, carrots and } \\
\text { lettuce }\end{array}$ & $\begin{array}{l}\text { Maize, pump- } \\
\text { kins, dry } \\
\text { beans, melons }\end{array}$ \\
\hline $\begin{array}{l}\text { Average total monetary value of production } \\
\left(\mathrm{R} \text { annum }{ }^{-1}\right)\end{array}$ & 41 & 211 & 213 \\
\hline $\begin{array}{l}\text { Average monetary value of production per } \\
\text { unit land }\left(\mathrm{R} \mathrm{m}^{-2} \text { annum }^{-1}\right)\end{array}$ & 1.58 & 1.07 & 0.61 \\
\hline $\begin{array}{l}\text { Average contribution of farming to total } \\
\text { household income in cash or kind (\%) }\end{array}$ & 0.2 & 0.7 & 1.5 \\
\hline $\begin{array}{l}\text { Average allocation of gross value of pro- } \\
\text { duction to home consumption (\%) }\end{array}$ & 100 & 78 & 100 \\
\hline $\begin{array}{l}\text { Average allocation of gross value of pro- } \\
\text { duction to sales }(\%)\end{array}$ & 0 & 22 & 0 \\
\hline
\end{tabular}

(1995) reported that an irrigated, continuously cultivated vegetable garden is able to provide $8 \mathrm{~kg}$ of fresh produce per $\mathrm{m}^{2} \cdot \mathrm{yr}^{-1}$. Despite the use of irrigation, the average annual yield obtained from home gardens in the study area was only about $0.8 \mathrm{~kg} \cdot \mathrm{m}^{-2}$ or $10 \%$ of the potential. The main reasons for the low productivity were discontinuous use of the available land, the limited use of fertilisers and constrained access to water as a result of distance to source, particularly in the high-lying parts of the settlements. On average, home gardeners harvested about $1.7 \mathrm{~kg}$ of fresh produce per month from their gardens. According to Schmidt and Vorster (1995) the recommended daily vegetable intake of children (younger than 15 years old) is $150 \mathrm{~g}$ and $200 \mathrm{~g}$ for adults. To meet the recommended daily intake of vegetables, the average-sized household in the study area needed to consume $810 \mathrm{~g}$ vegetables per day or $24.3 \mathrm{~kg} \cdot \mathrm{month}^{-1}$. On average, home garden production only provided $6.7 \%$ of this requirement, indicating that from a nutritional perspective, home gardening did not make an important contribution to household food security in the study area.

Group gardening occurred on land made available by schools, clinics or the Municipality. Production consisted entirely of western type vegetables. Water for irrigation was obtained from municipal taps, and in one case, from a borehole. Various irrigation systems were used, including the use of hosepipes, watering cans, sprinklers and drippers. The average size of land per participant was substantially larger than in the case of home gardening (Table 2), but annual production per unit area was lower at $0.54 \mathrm{~kg} \cdot \mathrm{m}^{-2}$, which was only $7 \%$ of the potential of $8 \mathrm{~kg}$ vegetables $\mathrm{m}^{-2}$ annum ${ }^{-1}$. Identified reasons for the low productivity were discontinuous use of the available land, limited use of fertilisers, lack of effective plant protection and constrained access to water. The main identified constraint in group garden projects was institutional uncertainty in terms of access to land and water. Several garden groups have had to transfer their project from one site to another when the land owners reclaimed their land. Where municipal water was used, the owners of the sites, in all cases public entities, such as the Municipality (vacant land on cemeteries), the Department of Education (school grounds) and the Department of Health (land attached to clinics) were responsible for payment of the water bill and this was a recurrent bone of contention between these entities and the garden groups. In the single case where a bore hole was used, payment of the electricity bill presented a financial constraint to the group. Taking into account that part of the produce was sold $(22 \%)$, group gardeners on average supplied their households with about $6.85 \mathrm{~kg}$ of fresh vegetables every month, which represented $28 \%$ of the recommended consumption of vegetables for an average household in the study area.

Crop production on open urban spaces resembled the dryland farming practised by rural households on arable allotments and involved the production of maize, dry beans and cucurbits during summer and the fallowing of the plot during winter. Other minor crops included bambara groundnuts and sweetpotatoes. Whereas these crops were grown for their seed, tubers or fruit in the case of cucurbits, during the growing season the leaves of both the cucurbits and the dry beans were harvested for use as 'morogo', which is the seSotho name for 'a leafy vegetable'. On average, the gross value of the produce obtained from dryland production of crops on open urban spaces was the highest among the three types of urban farming, even though the monetary value of leaf harvests was not considered in the valuation. Indications were that this type of farming supplied participating households with about one-quarter of their annual staple food requirements. In addition, the harvesting of leaves may have contributed to the intake of micronutrients such as calcium, vitamin A and iron for a period of about 30 to $45 \mathrm{~d}$, but no quantitative information on this benefit was collected.

The modest material contribution of urban farming to income and food security observed in Atteridgeville is not necessarily a universal feature of urban farming in South Africa. 
For example, May and Rogerson (1995) reported that urban agriculture contributed between $10 \%$ and $20 \%$ to the total household income of urban farmers in Tembisa and between $25 \%$ and $40 \%$ in Groutville. However, in both cases, farming occurred on a much larger scale than in Atteridgeville. In Tembisa, the average size of the plots was $5000 \mathrm{~m}^{2}$ and in Groutville, 3 ha.

Contrary to the observation by Schippers (2006) that home gardens in the urban areas of African cities were useful sites for the collection of germ-plasm of indigenous vegetables, these types of crops did not feature in the home gardens of Atteridgeville. Coetzee et al. (2006) also reported on the very limited occurrence of indigenous vegetables in the home gardens of Ga-Rankuwa, a poor urban settlement situated north-west of the City of Pretoria.

\section{The meaning of urban agriculture in the livelihood of participants}

Analysis of the interviews with participants showed that urban farming projects had multiple meanings in the livelihoods of participants, which differed to a certain extent among the three types of projects that occurred in the study area (Table 3).

Despite the relatively low contribution of urban farming to food security, particularly in the case of home gardening, production of food as a response to poverty, unemployment and food insecurity was the most commonly stated reason why households engaged in the different types of urban farming projects. Expressing cognition and social identity were also very important, particularly among home gardeners and those who practised dryland farming on open urban spaces. Women considered the production of food for their families as one of their roles in the household and applied the knowledge of food production they had acquired whilst living in rural areas to engage in urban farming projects. It was common practice among working men to provide their spouses with a specific amount of money every month and to expect their spouses to manage the domestic affairs with this allocation, including the provision of food. Irrespective of the type of farming project they were engaged in, women identified farming as a way to stretch the budgets they had been allocated and occasionally bought something small they considered important. In this way, women created some room to manoeuvre for themselves within the boundaries of male-controlled household budgets.

Socialisation was a central theme in group gardening. Participants used this activity to build relationships and networks and to provide a positive example of collaboration within a community of strangers and claimed that their engagement in group gardening had also assisted in combating the disintegration of their own families. Alienation and the disintegration of families are associated with urban poverty (Maswikaneng, 2003) and the results of this study showed group gardening to be an effective way of addressing these social problems. Similar findings were reported by Van Averbeke and Mei (1998) in a group garden project in Cradock, Eastern Cape Province.

\section{Conclusions}

This study demonstrated the importance of urban farming for societies in transition, such as South Africa. When poor rural people migrate to the city they often become poor urban people, at least initially, but their experience of poverty in the city differs from that in the rural areas where they came from. In terms of income they tended to be better off than their counterparts in the rural areas but social alienation and the disintegration of

\begin{tabular}{|c|c|}
\hline \multicolumn{2}{|c|}{$\begin{array}{c}\text { TABLE } 3 \\
\text { Reasons for residents of the informal settlements of } \\
\text { Atteridgeville to be engaged in different types } \\
\text { of urban farming projects }\end{array}$} \\
\hline \begin{tabular}{|l|} 
Theme \\
\end{tabular} & Specific reasons \\
\hline \multicolumn{2}{|l|}{ Home gardening } \\
\hline $\begin{array}{l}\text { Response to unem- } \\
\text { ployment, poverty } \\
\text { and food insecurity }\end{array}$ & $\begin{array}{l}\text { Obtain fresh food for the family } \\
\text { Access food when it is needed } \\
\text { Increase cash income by saving on } \\
\text { food expenditure }\end{array}$ \\
\hline $\begin{array}{l}\text { Spirituality, pleasure } \\
\text { and leisure }\end{array}$ & $\begin{array}{l}\text { Derive joy from work (in the garden) } \\
\text { Create a green environment }\end{array}$ \\
\hline Health & Maintain physical and mental health \\
\hline Existing capabilities & Apply knowledge of farming \\
\hline \multicolumn{2}{|l|}{ Group gardening } \\
\hline $\begin{array}{l}\text { Response to unem- } \\
\text { ployment, poverty } \\
\text { and food insecurity }\end{array}$ & $\begin{array}{l}\text { Save on food expenditure } \\
\text { Increase food security in terms of } \\
\text { quality, and access at all times } \\
\text { (coping when all else fails) } \\
\text { Reduce dependency on male- } \\
\text { controlled cash income } \\
\end{array}$ \\
\hline Socialisation & $\begin{array}{l}\text { Break out of isolation (community of } \\
\text { strangers) } \\
\text { Build a network of friends } \\
\text { Derive joy from working together } \\
\end{array}$ \\
\hline $\begin{array}{l}\text { Building a com- } \\
\text { munity }\end{array}$ & $\begin{array}{l}\text { Combat the disintegration of families } \\
\text { Present a living example of positive } \\
\text { co-operation } \\
\text { Care for the most disadvantaged } \\
\text { Train others technically and spiritually }\end{array}$ \\
\hline Spirituality & $\begin{array}{l}\text { Create green spaces } \\
\text { Maintain direct link with food }\end{array}$ \\
\hline Existing capabilities & Apply knowledge of farming \\
\hline \multicolumn{2}{|c|}{ Dryland farming on open urban spaces } \\
\hline $\begin{array}{l}\text { Response to unem- } \\
\text { ployment, poverty } \\
\text { and food insecurity }\end{array}$ & $\begin{array}{l}\text { Save on food expenditure } \\
\text { Feeding the family } \\
\text { Reduce dependency on male-con- } \\
\text { trolled cash income } \\
\text { Reduce dependency on unreliable and } \\
\text { irregular sources of income (especially } \\
\text { remitted income) } \\
\text { Supplement other sources of income } \\
\end{array}$ \\
\hline Gender and identity & Women are responsible to provide food \\
\hline Existing capabilities & $\begin{array}{l}\text { Utilise knowledge of producing food } \\
\text { Lack of skills to find urban employ- } \\
\text { ment }\end{array}$ \\
\hline
\end{tabular}

families are dimensions of poverty particularly associated with migration from rural to urban environments. Urban farming helps people who arrived recently in the cities from the rural areas to re-create elements of the rural environment they left behind, both physically and socially. It also helps them to cope with problems of identity which affect women in particular, because food production forms part of their traditional roles in family units. For this reason, interventions that promote urban agriculture for the purpose of improving human nutrition should target women. The current study showed that the contribution to total household income and food security of the three different types of farming found in the study area was generally modest. However, the benefits of urban farming in the livelihood of participants extended far beyond the material gain. For this reason, opportunities for farming should form part of urban planning 
that deals with providing residence for poor people arriving in the city from rural areas. Lack of space and limited access to water for irrigation were the main constraints that affected participants in urban farming in the study area. These constraints existed because urban farming was not considered when settlement in the study area was planned.

\section{References}

ADELZADEH A, ALVILlar C and MATHER C (2001) Poverty alleviation, employment creation and sustainable livelihoods in South Africa. In: Khosa MM (ed.) Employment through Economic Transformation [Online]. Available from: http://www.hsrcpress. ac.za/user uploads/tblPDF/1962 00 Employment through_Economic Transformation.pdf (Accessed on 19/05/2005).

ADATO M, CARTER M and MAY J (2004) Sense in sociability? Social exclusion and persistent poverty in South Africa. [Online]. Available from: http://www.sarpn.org.za/documents/d0001127/index.php (Accessed on 15/06/2005).

ALIBER M (2003) Chronic poverty in South Africa: incidence, causes and policies. World Dev. 31 (3) 473-490.

BABBIE E and MOUTON J (2001) Qualitative data analysis: The discovery of regularities. In: Babbie $\mathrm{E}$ and Mouton $\mathrm{J}$ (eds.) The Practice of Social Research (South African edition). Oxford University Press, Oxford. 498-501.

BORAINE A (ed.) (2004) State of the Cities Report. The South African Cities Network, Braamfontein. $198 \mathrm{pp}$

BURGESS A, MAINA G, HARRIS P and HARRIS S (1998) How to Grow a Balanced Diet: A Handbook for Community Workers. VSO Books, London. 229 pp.

CARTER M and MAY J (1999) Poverty, livelihoods and class in rural South Africa. World Dev. 27 (1) 1-20.

COETZEE MM, VAN AVERBEKE W and LIKUWANE IM (2006). Towards a holistic understanding of urban home gardening in poverty contexts. In: Proc. Int. Symp. on the Nutritional value and Water Use of Indigenous Crops for Improved Livelihoods. 19-20 September, University of Pretoria.[CD ROM]. Pretoria: The Centre for Nutrition, University of Pretoria: no page numbers.

DE VOS AS (2005) Qualitative data analysis and interpretation. In: De Vos AS, Strydom H, Fouché CB and Delport CSL (eds.) Research at Grass Roots for the Social Sciences and Human Service Professions (3rd edn.). Van Schaik, Hatfield, Pretoria. 333-356.

ELLIS F and FREEMAN HA (2005) Conceptual framework and overview of themes. In: Ellis F and Freeman HA (eds.) Rural Livelihoods and Poverty Reduction Policies. Routledge, London. 1-15.

JERVE AM (2001). Rural-urban linkages and poverty analysis. In: Grinspun A (ed.) Choices for the Poor: Lessons from National Poverty Strategies. UNDP, New York. 89-120.

MARTIN A, OUDWATER N and MEADOWS K (2000) Urban Agriculture and the Livelihoods of the Poor in Southern Africa: Case Studies from Cape Town and Pretoria, South Africa And Harare, South Africa. Natural Resource Institute, Chatham. 45 pp.

MASWIKANENG MJ (2003) Urban Agriculture in the Informal Settlements of Atteridgeville, Pretoria. M. Tech. (Agric.) dissertation, Department of Agricultural Management, Technikon Pretoria, Pretoria. $187 \mathrm{pp}$.
MASWIKANENG MJ, VAN AVERBEKE W, BÖHRINGER R and ALBERTSE E (2002) Extension domains among urban farmers in Atteridgeville (Pretoria, South Africa). J. Int. Agric. Ext. Educ. 9 (2) $15-22$.

MAY J (2000) The structure and composition of rural poverty and livelihoods in South Africa. In: Cousins B (ed.) At the Crossroads: Land and Agrarian Reform in South Africa into the 21 $1^{\text {st }}$ Century. Programme for Land and Agrarian Studies, University of the Western Cape, Belville: 21-34.

MAY J and ROGERSON C (1995) Poverty and sustainable cities in South Africa: the role of urban cultivation. Habitat International 19 165-181.

POTGIETER JF (1999) The Household Subsistence Level in the Major Urban Centres of the Republic of South Africa (September 1999). Fact Paper No 107. Institute of Planning Research, University of Port Elizabeth, Port Elizabeth. 54 pp.

RAKODI C (1999) A capital assets framework for analysing household livelihood strategies: Implications for policy. Development Policy Review 17 (3) 315-334.

ROGERSON CM (1993) Urban agriculture in South Africa: policy issues from international experience. Development Southern Africa 10 (1) $33-44$.

ROGERSON CM (1996) Urban poverty and the informal economy in South Africa's economic heartland. Environment and Urbanisation 8 (1) $167-179$.

SCHIPPERS RR (2006) Traditional vegetables in Africa. In: Proc. Int. Symp. on the Nutritional value and Water Use of Indigenous Crops for Improved Livelihoods. 19-20 September, University of Pretoria. Volume of invited papers, peer-reviewed extended abstracts and short abstracts. Pretoria: The Centre for Nutrition, University of Pretoria. 2-12.

SCHMIDT MI and VORSTER HH (1995) The effects of communal gardens on nutritional status. Dev. South. Afr. 12 (5) 713-725.

STATISTICS SOUTH AFRICA (2007) Annual Inflation on a monthly basis: Consumer Price Index. [Online]. Available from: http://www. statssa.gov.za/keyindicators/CPI/CPIHistory.pdf [Accessed on 23/03/2007].

STRYDOM H (2005) Sampling and sampling methods. In: De Vos AS, Strydom H, Fouché CB and Delport CSL (eds.) Research at Grass Roots for the Social Sciences and Human Service Professions ( $3^{\text {rd }}$ edn.). Van Schaik, Hatfield, Pretoria. 192-204.

SWIFT J and HAMILTON K (2001) Household food and livelihood security. In: Devereux S and Maxwell S (eds.) Food Security in SubSaharan Africa. ITDG, London. 67-92.

THERON M (2000) Inadequate Dietary Intake as the Cause of Stunting amongst Children aged 12 to 24 Months living in an Informal Settlement in Gauteng. M. Tech. Dissertation, Technikon Pretoria, Pretoria. $234 \mathrm{pp}$.

UNDP (2004) South Africa Human Development Report: The Challenge of Sustainable Development in South Africa, Unlocking People's Creativity. Oxford University Press, Oxford. 295 pp.

VAN AVERBEKE W and MEI P (1998) Evaluation of Masizakhe Agricultural Project: An Irrigated Community Garden in Lingelihle Township, Cradock. ARDRI Report 1/98. Agricultural and Rural Development Research Institute, University of Fort Hare, Alice. $54 \mathrm{pp}$. 